\title{
The Organization of Markets for Collective Concerns and Their Failures
}

\author{
Frankel, Christian; Ossandón, José ; Pallesen, Trine
}

\author{
Document Version \\ Accepted author manuscript \\ Published in: \\ Economy and Society \\ DOI: \\ $10.1080 / 03085147.2019 .1627791$ \\ Publication date: \\ 2019 \\ License \\ Unspecified
}

Citation for published version (APA):

Frankel, C., Ossandón, J., \& Pallesen, T. (2019). The Organization of Markets for Collective Concerns and Their Failures. Economy and Society, 48(2), 153-174. https://doi.org/10.1080/03085147.2019.1627791

Link to publication in CBS Research Portal

\section{General rights}

Copyright and moral rights for the publications made accessible in the public portal are retained by the authors and/or other copyright owners and it is a condition of accessing publications that users recognise and abide by the legal requirements associated with these rights.

\section{Take down policy}

If you believe that this document breaches copyright please contact us (research.lib@cbs.dk) providing details, and we will remove access to the work immediately and investigate your claim.

Download date: 26. Apr. 2023

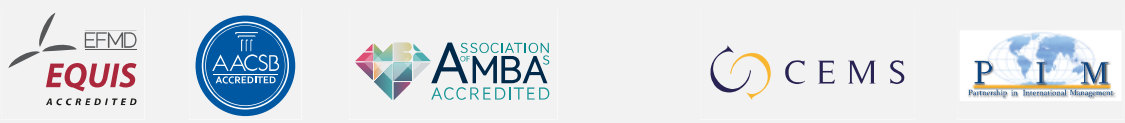




\section{The Organization of Markets for Collective Concerns and Their Failures}

\section{Christian Frankel, José Ossandón, and Trine Pallesen}

Journal article (Accepted manuscript*)

\section{Please cite this article as:}

Frankel, C., Ossandón, J., \& Pallesen, T. (2019). The Organization of Markets for Collective Concerns and Their Failures. Economy and Society, 48(2), 153-174. https://doi.org/10.1080/03085147.2019.1627791

This is an Accepted Manuscript of an article published by Taylor \& Francis in Economy and Society on 16 Jul २०19, available online:

DOI: http://www.tandfonline.com/10.1080/03085147.2019.1627791

* This version of the article has been accepted for publication and undergone full peer review but has not been through the copyediting, typesetting, pagination and proofreading process, which may lead to differences between this version and the publisher's final version AKA Version of Record.

Uploaded to CBS Research Portal: May २०२० 


\title{
The Organization of Markets for Collective Concerns and their failures ${ }^{i}$
}

\section{Christian Frankel, José Ossandón and Trine Pallesen}

Christian Frankel, Department of Organization, Copenhagen Business School, Kilevej 14A, 4th floor, DK-2000 Frederiksberg, Denmark.E-mail: cf.ioa@cbs.dk

José Ossandón, (corresponding author), Department of Organization, Copenhagen Business School, Kilevej 14A, 4th floor, DK-2000 Frederiksberg, Denmark.E-mail: jo.ioa@cbs.dk

Trine Pallesen, Department of Organization, Copenhagen Business School, Kilevej 14A, 4th floor, DK-2000 Frederiksberg, Denmark.E-mail: tp.ioa@cbs.dk

\begin{abstract}
This special issue introduces a new object of analysis: the organization of markets for collective concerns and their failures. This paper discusses how the study of this new object challenges key assumptions in recent social studies of markets. We focus on three issues, each related to the keywords of the title: organization, market, and concern. The first problem is the fluctuating conceptual value of the market-organization pair in the forms of expertise used to implement and repair markets for collective concerns. The second challenge pushes social researchers to develop a stronger analytical sensibility to the identification and understanding of the concepts of markets mobilized in their fields. Third, we show how the consolidation of professions involved in practices of market design challenges the political expectations found in social studies of markets.
\end{abstract}

Keywords: markets; neoliberalism; economic sociology; formal organization; economists; market design.

A new object of analysis: the organization of markets for collective concerns and their failures

As Foucault (2008 [1978-9]) pointed out 40 years ago, the economic thinking of the Ordoliberals in Germany, the Chicago School in the United States, and Austrian economists such as Hayek, represented an important shift in the way social problems are conceived and governed. As these ideas were implemented more widely, the market acquired a new type of function (Mirowski, 2013, Dardot \& Laval, 2013). Markets - or some of the features attributed to markets, such as choice, competition and price - started to be purposely introduced as means to solve pressing collective problems or concerns. Markets became instruments of policy in areas such as health care, public transport, education and environmental pollution. Such markets are the focus of this special issue. We use the term markets for collective concerns to name this particular object of study. 
To relate markets and concerns is certainly not new. For instance, according to the editors of a recent book (Geiger et al., 2014), most markets are concerned markets in the sense that they are affected by - or provoke - ethical, moral or environmental concerns, and consequently they are often repaired in order to respond to these concerns. More generally, most — if not all — markets are products of some form of organized collective action. For example, in their renowned study, MacKenzie and Millo (2003) demonstrated how the Chicago Board Options Exchange has been constructed, and even carefully designed, by a set of actors motivated by specific collective purposes. However, neither the Chicago Board Options Exchange nor most of the cases included in the book edited by Geiger and colleagues correspond to what we here call markets for collective concerns. Markets for collective concerns identify a more distinct empirical object, namely cases that are simultaneously markets and 'policy instruments' (Lascoume \& Le Gales, 2007).

The papers in this issue offer careful empirical descriptions of what happens after the implementation of markets for collective concerns. What the research presented in this issue shows is an important transition: from a form of policy-making that assumed that, once implemented, markets work on their own, to situations in which policy-making is understood as continuous market organization. Policy-making becomes the evaluation, diagnosis, design and repair of markets. This new form of governing is the important societal problem this issue helps us to better understand. The 'organization of markets for collective concerns and their failures' names the new terrain explored in this issue.

Besides this introductory piece, five contributions comprise this issue. The first four papers are case studies: Ossandón and Ureta study the markets for public transport and health care in Chile; Reverdy and Breslau, the market for wholesale electricity in France; Doganova and Laurent, markets for emissions, sustainable biofuel and clean technologies in Europe; and Neyland, Ehrenstein and Milyaeva, markets for electronic waste and childcare in the United Kingdom. ${ }^{\text {ii }}$ Despite the differences in terms of their thematic and geographic scope, the inspection of the discourses and practices involved in governing collective concerns with markets show important similarities. First, the different cases of markets for collective concerns have been problematized as failures by the relevant actors in these different fields of inquiry. Even more significantly, the different cases show that failure does not pave the way for the introduction of non-market forms of solving collective problems. Instead, the cases show an important reorientation in the practice of policy-making and the consolidation of new types of policymaking expertise. These experts are not simply market enthusiasts, but their claim of expertise is that they know how to assess, identify and repair market failures. For the relevant experts in the different cases presented here, the problem of how to make particular markets work well becomes, to use an ANT expression, 'the obligatory point of passage'. Policymaking becomes market organization. The fifth paper, by Nik-Khah and Mirowski, provides the intellectual context for this important development. They trace the transformation in economics, from a professional consensus that assumed that markets were the opposite of planning, to the current context in which economists claim to be experts in the design of markets.

The role of this introductory paper is to add a conceptual reflection. The question that guides this piece is: how does the study of the organization of markets for collective concerns challenge our understanding of markets? Our focus on the challenges, certainly, does not mean that there are no relevant conceptual tools already available. In fact, as per a point we will explore further below, the contributions to this issue draw extensively on tools developed in an inter-disciplinary 'social studies of markets' literature. ${ }^{\text {iii }}$ Our claim is that the empirical terrain explored in this issue poses new questions and problems to the dominant social scientific literature in this area. These are the challenges that future research on the use of markets in the government of collective concerns will 
have to address. The main goal of this introduction is to pose these challenges. The argument unfolds in three steps, each related to the three key words in the title of this chapter: organization, market, and concern.

The first part of this argument is about organization. We suggest that that the study of markets for collective concerns pushes social scientists to inspect the complex and convoluted conceptual history of the pair market-organization. It is broadly accepted within recent social studies that markets are organized. The study of markets for collective concerns pushes this claim further. It is not only that markets require organizing or that they are the outcome of organized collective action. Markets for collective concerns are markets that have some of the features normally associated with formal organizations. These are markets oriented to specific purposes and requiring constant expert design and planning, and this represents an important twist in the conceptual history of the marketorganization pair. The second part is about the notion of 'market'. The cases introduced in this issue present the researcher with situations in which the actors studied are experts in markets. We argue that this requires an important modification in the conceptual stance adopted by social researchers. Sociologists of different traditions share the view that part of their task is to provide definitions of markets. In the study of markets for collective concerns, however, the different understanding, definition and concepts of markets mobilized by those we study become part of the object of analysis. The third part of the discussion is about the notion of 'concern'. So far, we have used the term 'concern' in some of its most common usages in English ${ }^{\text {iv }}$ referring to markets that have been devised to deal with matters or issues of collective interest. The notion concern, though, has been used as a more specific concept in Actor-Network Theory and in the very influential ANT-inspired studies of markets. This section shows how the cases presented in this issue importantly challenge this literature. In short, unlike Callon's (2009) proposal in his 'Civilizing markets' article, the empirical analyses presented in this issue show that problematization of markets for collective concerns does not open up democratic forums where the voices of affected and concerned groups are recognized and heard. Instead, we see the development and consolidation of new types of expertise and deliberation that exclude solutions which are not framed in terms of market organization.

\section{The organization in the organization of markets for collective concerns}

We term the shared object of analysis in this special issue the 'organization of markets for collective concerns and their failures'. But what does it mean to say that markets for collective concerns are organized? The answer is not simple. It could mean very different things. Recent social studies of market literature agrees that empirical markets can be analyzed as cases of organization. The first sub-section below shows that this is no less true for markets for collective concerns. But markets for collective concerns are not simply like organizations - they have also developed in a particular and changing relation with organization. The second sub-section is a brief exploration of the fluctuating value of organization in the intellectual context of markets for collective concerns. The challenge for social studies of markets is to better account for such changes and conceptual transformations.

\section{Markets for collective concerns are organized}

While economists have tended to see markets in opposition to organization, recent economic sociology has started from the opposite heuristic. Despite differences in methods and concepts, 
various streams in the social studies of markets analyze markets as instances of organization. This operation has also proved useful when studying markets for collective concerns.

In the opening to The laws of the markets, Callon (1998a, p. 3) states: 'the market implies an organization'. A few years later, Callon and Muniesa added that markets can be understood as 'organized calculative devices' (Callon \& Muniesa, 2005, p. 1230). 'Calculability', in this context, is neither a natural capacity of human agents nor a property of objects. It is an achievement; the outcome of the organizing work conducted by the actors and devices involved in activities such as displaying, marketing, ranking, assessing, and so on. The insight that markets require socio-technical organizing work is also relevant for the study of markets for collective concerns. In their contribution to this issue, Doganova and Laurent use the approach initiated by Callon to compare the socio-technical organization work deployed in the enactment of three different market policy instruments (the Emissions Trading System, the market for clean technologies, and the market for sustainable biofuel) in Europe. The comparison shows how the frame that delimits what is economic and what is political varies in the different cases. Previously, MacKenzie (2009) showed how carbon markets need costly socio-technical organizing work to make heterogeneous entities-like the emissions of an energy plant in Scotland and the future carbon reduction introduced by a new plantation of trees in Brazil equivalent.

Another influential body of work within social studies of markets understands markets as a type of political system (Bourdieu, 2005; Fligstein, 1996). Neil Fligstein, one of the most recognized proponents of this position, has suggested the metaphor 'markets as politics' (Fligstein, 1996) to highlight the mechanisms by which firms' struggles to control their area of action end up defining the shape of particular industries. Fligstein's approach to markets strongly resembles the approach to organizations developed by James March (1962) some decades before. Fligstein's markets are, like March's organizations, understood as political arenas with coalitions and collective interests, where the overall purpose, or 'conception of control', is the outcome of struggles between these coalitions. ${ }^{\mathrm{v}}$ Markets are understood as fields of organized action. This insight has also been used in the understanding of markets for collective concerns. In their contribution to this issue, Reverdy and Breslau show that their case - the market for energy created in France in the context of liberalization reforms - resembles regulated industries, where business success and the ability to frame the norms and rules of the particular exchange are tightly coupled to the struggles of firms trying to define them. Similarly, in a previous publication, Ossandón (2015) discusses how Fligstein's concepts can be used to understand the political action of actors such as the industry association in the organization of the health insurance market created as a policy instrument in Chile. Competition, in these cases, is not simply about attracting customers but also over the delimitation of the norms and rules that define practices that are, and are not, accepted in a given industry.

We could go one step further, and show how markets for collective concerns present yet other features associated with conceptualizations of organizations that have not been considered in the papers in this issue nor in previous research in the area. For instance, organization theorists Ahrne $e t$ al. (2015) suggest that markets are organized as they usually feature some of the aspects of the definition of formal organization. For example, markets often require formalized decisions on issues such as membership, rules, monitoring, hierarchy and sanctions. Similarly, it could be argued, markets for collective concerns studied in this issue (as in the cases presented by Neyland and colleagues, Doganova and Laurent, and Reverdy and Breslau) present rules that define membership, have specialized regulation and regulatory bodies, and these bodies can monitor and sanction the activities of market participants. In their recent study of classical organization theory, du Gay and Vikkelsø (2017) conclude that, for authors such as Chester Bernard, what distinguishes an 
organization is the existence of a collective 'task' or 'purpose'. As March and Simon (1993) explain in their classical treatment, what formal organizations do is to implement programmes of actions that attempt to adapt the functioning of the organization to its purposes. As shown in the contributions by Ossandón and Ureta and Neyland et al., markets for collective concerns could also be seen as organizations in this sense. The work of economists and other experts, like the executive in the formal organization, is oriented to assessing the relationship between market and purpose and initiating programmes of action with the intention to improve their fit.

\section{Markets for collective concerns for and against organization}

Social studies of markets see markets as instances of organization. This operation is also useful in studying markets for collective concerns. Markets for collective concerns are the outcome of sociotechnical organizing work needed to stabilize goods and economic frames; they are an active arena of organized collective political struggles; and they share features associated with formal organization. Markets for collective concerns are like organization. What the work mentioned here does not explain, however, is the particular tension between organization and markets that is inscribed in the history of markets for collective concerns. Markets for collective concerns are not only like formal organization; they also exist in a particular and changing relation with organization. We cannot rehearse the history fully here. The following paragraphs outline only some basic aspects.

The pre-history of markets for collective concerns is connected to the strong intellectual and ideological movement against formal organization, in particular bureaucracy, developed in the early twentieth century (Bendix, 1945; Blau \& Meyer, 1971). Not only was bureaucracy criticized in terms of its excess formalism, but also, most prominently by authors such as Hayek and Mises, in terms of its rationality and efficiency. These authors questioned key ideas, often inspired by Weber's work, that bureaucratic organization was the most effective way to achieve a given task. ${ }^{\mathrm{vi}}$ As Reinhard Bendix summarized:

Some, like von Mises, insist that economic rationality can be obtained only under free competition, since no other system provides the possibility of calculating assets against liabilities. All other economic systems are, therefore, economically irrational (i.e. inefficient), since in them the allocation of resources must be arbitrary. (Bendix, 1945, p. 201).

There was, however, at that time a relative consensus, shared even by economists like Mises, that government should have privilege over certain tasks. One such task was to act in the case of market failures: taxes to deal with externalities, anti-trust regulation to avoid monopolies, or regulated monopolies for public goods. This consensus was challenged after Coase and others turned the notion of market failure upside down. Under these new lenses, externalities are - under certain conditionsbetter dealt with through market mechanisms. ${ }^{\text {vii }}$ For instance, instead of taxing or banning harmful economic activities, it became conceivable that governments could create a market of rights to emit emissions in order to deal with carbon pollution (Lohmann, 2009). Also following Coase, neoinstitutional economists started to assume that markets and organization (organizations here understood as hierarchies) can be compared as means to attain similar goals - hierarchies would be preferred only in those situations where transaction costs are too high to enable market exchange (Coase, 1937; Williamson, 1979). 
Under neoliberal scrutiny, bureaucracy, the ethics of office and formal rule as favoured means to solve collective issues, are questioned. Instead, competition and price start to be championed as prominent alternatives. In this context, as Foucault (2008[1978-9]) pointed out in his analysis of the Ordoliberals in Germany and the Chicago School, market competition started to be seen not only as something that needs to be protected from state intervention, but it becomes a goal that governments, advised by economists, actively pursue, enact or incentivize. As more recent analyses show (Mirowski, 2013; Cooper, 2011), neoliberalism did not simply expand the use of neo-classical markets, but produced a new conception of what markets are and can do. Market competition, for authors like Hayek (1991) or Buchanan and Vanberg (1991) is not only different from bureaucracy, but, more generally, it opposes organization and planning. Market competition is here understood as a type of distributed collective intelligence mechanism that outperforms planning or democratic decision-making in the task of searching for innovative solutions to uncertain problems. ${ }^{\text {viii }}$ In other words, markets are not simply conceived as the particularly efficient mechanism to coordinate the circulation of existing scarce resources, as in the traditional neo-classical view, but are increasingly seen as the source of possible solutions. But once instituted, neoliberal economists would argue, markets should be left alone, as expert knowledge, planning and more general regulation could never match the knowledge-processing ability of spontaneous competition.

The early traces of the idea that markets could be implemented as policy instruments to deal with collective concerns can thus be understood as the result of the problematization of bureaucracy in the mid-twentieth century and the development of a new understanding of markets as mechanisms to solve collective issues. ${ }^{\text {ix }}$ To borrow the terminology from conceptual history (Koselleck, 2004; Luhmann, 1980), we could say that the development of markets for collective concerns was accompanied by a 'semantic' that opposed markets to formal organization, and in particular bureaucracy. In this sense, the analysis of markets for collective concerns cannot simply dispense with the conceptual dichotomy that opposes market and organization. Markets for collective concerns are the outcome of a conceptual milieu in which it became possible to imagine bureaucracy and markets as alternative instruments to deal with collective problems.

Markets for collective concerns emerged against organization. However, as the different papers in this issue show, they have also opened the space for a new type of expertise which assumes that, in order to work as good policy instruments, markets require continuous organization. As Nik-Khah and Mirowski show in their contribution to this issue, what has yet to be explained is the huge u-turn from the intellectual context of mid-twentieth- century characterized by a strong opposition between formal organization and markets, to the situation today, where it has become a common assumption amongst economists that in order to work well, markets need to be organized. As they compellingly put it:

prior to the 1970s, no economist in the history of neoclassical economics claimed an ability to fix markets to bring about salutary results; more conventionally, the task of rectifying so-called 'market failures' fell to the government. Yet something changed in the 1980s, such that by now it has become commonplace for orthodox economists to assume carte blanche to concoct markets in a smorgasbord of shapes and flavours, for sale to all manner of patrons. (Nik-Khah \& Mirowski, 2019).

Recent movements - like market design, but also information and behavioural economics - that drive the expert problematization and repair of markets for collective concerns, assume that markets do not work spontaneously, but need experts in charge of engineering purposively developed mechanisms 
to tune them to their task. This new post-neo-classical, but also post-Hayekian, view is clearly summarized by market designer John McMillan:

When markets are well designed - but only then - we can rely on Adam Smith's invisible hand to work, harnessing dispersed information, coordinating the economy, and creating gains from trade. (McMillan, 2002, p. 228).

The challenge posed by the papers in this issue to existing social studies of markets is to make sense of the fluctuating meaning and value of organization in the ideas used to problematize and repair markets for collective concerns. So far, one of the main particularities of social studies of markets has been that they challenge economists' views to some extent by stressing that markets - and markets for collective concerns too-are not in opposition to organization, but they are organization. More generally they insist that, contrary to the view of many economists, markets are constructed, practically organized social or socio-technical mechanisms (e.g. Jenle \& Pallesen, 2017). But what the study of markets for collective concerns shows is that, increasingly, economists see themselves as 'market designers' who knowingly construct markets. This apparent contradiction, we think, might push social studies of markets to a stronger collaboration with conceptual and economic history. NikKhah and Mirowski, in their contribution, take the first steps in this direction: they follow the particular intellectual trajectory that combined some of Hayek's ideas with those developed within the Cowles Commission to form a brand-new form of market understanding, namely markets as information-processing organizations. ${ }^{\mathrm{x}}$ This historical dimension is very relevant, because in order to understand the work of the expert we study we need to grasp better the particular (and sometimes contradictory) baggage they mobilize.

\section{The markets in the organization of markets for collective concerns}

The study of markets for collective concerns, we claim, opens up new questions in relation to the conceptualization of markets.

To begin, consider the following three quotations. In his famous introduction to The laws of the markets, Callon argues:

the market is a process in which calculative agencies oppose one another, without resorting to physical violence, to reach an acceptable compromise in the form of a contract and/or a price. (Callon, 1998a, p. 3).

Fligstein, in The architecture of markets, says:

A market is a social arena where sellers and buyers meet. But for sellers and buyers to exist, a product has to exist and someone has to produce it. A market depends on the buyers continuing to "show up" in a particular social space to purchase the product. (Fligstein, 2001, p. 37).

In the more recent piece titled 'The organization of markets', Ahrne and colleagues suggest:

A market is a social structure for the exchange of owners' rights, in which offers are evaluated and priced, and in which individuals or organizations compete with one 
another via offers (Aspers, 2011). The social structure comprises two roles of exchange - sellers and buyers - both of whom have owners' rights [...] (Ahrne et al., 2015, p. 9).

The quotations introduce broad - yet distinct - definitions of markets. Surely, few researchers in the social studies of markets field would disagree with such definitions. However, what the study of markets for collective concerns challenges is the basic fact that these authors start their inquiry with their own definition of markets. An important empirical problem posed by markets for collective concerns is that the practitioners involved in these cases bring their own definitions or conceptions of markets and different definitions of markets might co-exist in the field. As Frankel has put it, there is a 'multiple market problem' (Frankel, 2015, 2018), which calls for a higher degree of attention to the specificity of the notions of 'market' at work in the empirical field studied.

Take for instance previous work by Breslau $(2011,2013)$ on the electricity sector in the United States. Unlike many other countries where electricity has been provided by state-owned firms, electricity generation and distribution in the US has long been in the hands of private companies clustered in geographically regulated monopolies. The liberalization reforms carried out in this sector from the 1980s sought to challenge such monopolies by introducing organized exchanges. Once introduced, however, these reforms in turn created new problems, and these new problems led to the emergence of a group of market experts, who competed over the formulation of the official version of the market's problems. These experts, as Breslau points out, perform what he calls 'applied Platonism': they compare existing concrete arrangements with different conceptualizations of ideal markets, and from this normative comparison they diagnose problems and provide possible reparative solutions. In their evaluations, market designers mobilize different conceptions of what an ideal market is, changing in turn the type of market constructed.

The existence of different conceptions of markets is not only an issue related to recent market design. What the paper by Ossandón and Ureta in this issue shows, is that there has been an important although largely invisible transformation in the concepts of markets used to evaluate and problematize specific market arrangements in Chile. For instance, when a market for health insurance was created in the early 1980s, the assumed notion of markets used in the reform was close to Hayek's ideas, where markets were understood as a spontaneous combination of choice, supply, demand, price and property rights, characterized in opposition to state bureaucracy. The evaluation of this marketization reform conducted a decade later assumed a different conception of markets, inspired this time by information economics, where the key conceptual dichotomy is not against bureaucracy, but between perfect competition and market failure.

Recent developments in the problematization of markets for collective concerns represent an important challenge to the ways in which the concept of market has been understood in social studies of markets. Since Weber, social researchers have taken it upon themselves to produce stylized conceptions of what an ideal type of market is, leaving for empirical analysis the study of the social dynamics and mechanisms that characterize them (Aspers, 2011). What characterizes recent studies of markets for collective concerns, though, is a shift in the position of the sociologist studying markets: it prompts increased attention to the concepts of markets at work or as mobilized by the actors analyzed. Here, it might be useful to reorient one of Fligstein's propositions. In Fligstein's view, markets are not only arenas of political struggles but are also fields in which actors try to stabilize a particular 'conception of control'. Firms orient their action not only towards securing a strong position in relation to other firms, but also towards the stabilization of the institutional norms, such as standards or anti-trust regulation, that define how the specific market has to be understood and regulated. We could say that the problem in markets for collective concerns is not only about 
studying actors competing to provide a different conception of control in a specific industry. Instead, close attention should also be paid to the emerging field of experts competing to provide what we could term different 'conceptions of markets' - the different definitions and understandings of markets mobilized by those in charge of evaluating and repairing an existing market for collective concern. In this context, the struggles are not only between companies competing for success in a given field, but just as importantly amongst market designers defining the market concepts against which actual markets are modelled (Mirowski \& Nik-Khah, 2007; Breslau, 2013). We think future studies of markets for collective concerns would benefit from a broader awareness of the different concepts of markets, and their history, involved in their practical evaluation, repair and design.

\section{The concerns in the organization of markets for collective concerns}

As previously mentioned, one of the - if not the - most influential streams in recent social studies of markets is work inspired by Callon's reorientation of Actor-Network Theory. While being informed by this perspective, the papers in this issue importantly challenge some key aspects in this tradition, particularly in the expected relationship between markets and concerns. This argument unfolds in two steps. The first step briefly recalls the ANT-inspired approach to markets and concerns, and the second explains the challenges posed to this perspective by the study of markets for collective concerns.

\section{Actor-Network Theory on markets and concerns}

Since the early developments of this approach, Actor-Network Theorists have paid special attention to three main moments: (i) the scientific work involved in putting problematic scientific issues into stabilized black boxes; (ii) how controversies open previously black boxed objects; and, (iii) how within these controversies new forms of technical problematization and expertise develop (Callon, 1981). The very influential approach to the study of markets initiated by Michel Callon is not dissimilar. From this perspective (Callon, 1998a; Callon et al., 2002; Caliskan \& Callon, 2010), markets are understood as socio-technical frames that enable the transformation of unqualified things into calculable qualified goods. Likewise, the framing of the economic object is not always stable. It is often 'overflowed' by issues and actors previously not taken into account (Callon, 1998b) and these overflows, in turn, trigger expert efforts to re-frame and to make the qualities of the relevant economic goods stable again. ${ }^{\mathrm{xi}}$

The interest in the tension between stable technical objects and controversies has remained relevant in more recent ANT-inspired research. The stance of this work has, however, changed. This transition is clearly staged in Latour's (2004) piece which introduces the distinction between 'matters of facts' and 'matters of concerns'. In this formulation, ANT is no longer only concerned with describing the different actors involved in scientific innovation and socio-technical controversies. The movement from matters of facts to matters of concerns signals a new mode of engagement. Social researchers not only follow other actors; they are expected to be among those who are concerned with the matter at hand, for instance ecological disaster. Not unlike Latour, Callon's interest in markets and concerns has moved beyond a mere descriptive stance. As mentioned, in Callon's early work, scientific fact-making was understood as networks of 'problematization' where the role of the social researcher was to follow the process in which unclear, controversial issues were made into delimited 
objects of knowledge, measurement and control. In his more recent work, the interest in problematization stays; however, the angle of his position is no longer that of a 'second order' observer of the work of experts involved in socio-technical controversies.

A case in point is Callon's own article on C02 markets (Callon, 2009). In response to his own rhetorical question - 'what is a market that works correctly?' - Callon answers:

it is a market which welcomes and recognizes as one of its most central constituent elements all the actors who demand to be taken into account, including those who are considered as marginal, or on the verge of exclusion, with their points of view, their matters of concern, their proposed tools, framings and modes. It is this dynamic tension, in which constant unexpected concerns are expressed and ask to be heard and to be taken into consideration that defines a "good" market. (Callon, 2009, p. 541)

As the quotation shows, Callon's recent work sets specific normative expectations about the role of markets in collective concerns and he delimits a new role for the social scientist in this context. The expectation is that markets for collective concerns will become also civilized markets. Markets that are civilized, in this context, are markets supplemented with well-functioning hybrid forums ${ }^{\mathrm{xii}}$. Carbon trading, from this point of view, is not only an ambitious policy instrument set to deal with one of the most pressing global collective concerns, it is eventually the source for a new type of market, which can be both an economic exchange and a forum that deals with the matters of concerns of its own functioning. By introducing the notion of civilizing markets (Ossandón, forthcoming), Callon also implicitly introduces the idea of a 'non-civilized market', and in doing so, he places himself and social scientists that use his work in a position which is not unlike the one adopted by economists explored in several of the papers in this issue. Rather than following the ways in which market agents and goods are continuously valued and re-qualified, it is the market which is made the object of valuation. What Callon appears to suggest, as the next quotation illustrates, is including social researchers in the list of possible experts whose voice could or should be heard at the moment of evaluating existing markets that are also policy instruments:

To be considered as efficient, a market should pay very careful attention to the numerous matters of concern that it creates, and to the groups that express and promote them, thus becoming economic agents in their own right. (Callon, 2009, p. 546)

\section{Are markets for collective concerns civilized?}

ANT's emphasis on socio-technical controversies has inspired some of the papers in this issue in important ways. The four case studies included pay special attention to the role of problematization in the active transformation of collective concerns into market problems. These studies show that markets for collective concerns are open for contestation, reassessment and evaluation and how, in the identification of failures, new actors and experts emerge or are consolidated. However, these studies also challenge the expectation of civilizing markets and the role attributed to the social scientist in this context.

Studies like those conducted by Neyland et al., Ossandón \& Ureta, show that when markets for collective concerns become objects of controversy new experts and forms of problematization emerge (see also Pallesen, 2016). However, these controversies are not necessarily 
'civilized' in the sense used by Callon. The overflows produced by the markets discussed here have mostly been dealt with by economists or engineers. It is as if Callon's approach suffers a similar problem as one detected in Beck's work. In Beck's view, the rise of new types of manufactured uncertainties would challenge the actuarial possibilities of existing ways of dealing with collective problems, for instance insurance, opening the space for new forms of deliberative politics. Empirical work, however, showed that, although challenged, the insurance industry found creative ways of technically dealing with new uncertainties (Ericson \& Doyle, 2004). Similarly, Callon seems to assume that market failures overflow economic expertise, opening a gap for forums where those concerned by these failures can deliberate. Empirical research on markets for collective concerns, however, shows that experts involved in these markets have also found ways to avoid deliberative participation. Labels such as 'market design' signal the emergence of a new type of professional claim - economists and engineers who are experts in dealing with market failures.

Rather than the figure of the civilizing market, we could say that the study of the ways in which markets for collective concerns have been empirically problematized is closer to a - by now almost forgotten - concept from the sociology of organization of the mid-twentieth century, namely Robert Merton's notion of 'displacement of goals' (Merton, 1940). Merton's point is that, while bureaucracy tunes organizations towards their purposes, it happens sometimes that the means - for instance formal rules - become more important than the goals. In markets for collective concerns, it is the market - which was supposed to be a solution to some of the problems attributed to bureaucracy that displaces the goal. Markets for collective concerns are markets that have been constructed as policy instruments because policy makers supposedly expected them to offer the best possible solution to a particular collective problem. However, once markets have been found problematic, evaluation and repair is not oriented towards finding other means to reach that specific goal. Instead, attention is re-oriented towards the repair of markets so they can work as good markets. What contemporary trends such as market design and behavioural economics show, beside an important change from market spontaneity to an explicit orientation towards expert intervention and design, is a fixation with markets.

Finally, the stance taken by Callon in his later work, which situates researchers in the position of observing policies in terms of well- and poorly- functioning markets, might prove problematic. As Ossandón and Ureta suggest, the issue at stake here is not that markets for collective concerns are not criticized or questioned - they are — but rather that the problematization of markets for collective concerns has ended up excluding the possibility of problematizing existing policies in ways other than as poorly functioning markets. A key empirical finding of the papers in this issue is that the experts in the different cases are fixated by markets being solutions to the most varied collective problems. Callon's ideal of a civilized market pushes social scientists to place themselves in a similar position. It is as if (see Stengers, 2014, for an argument in this direction) the best means to solve collective concerns are already set (in his case 'civilized markets). What we supposedly have to do is to work to make markets work properly. A question that we can only ask, but certainly not solve, for future studies is whether this is the only role social scientists can play in markets for collective concerns. 


\section{Contributions and concluding remarks}

To end, let us introduce the contributions. Beside this opening piece, five papers comprise this issue. They represent great variation in the empirical situations they study and cover 40 years of experimentation with markets for collective concerns.

In their contribution, Ossandón and Ureta compare transport and healthcare market-based policies introduced in the early 1980s in the context of Pinochet's dictatorship in Chile. Their study focuses on the moment in which these reforms started to be questioned in the 1990s and explores the early development of a new type of policy-making where the justification of important and radical policy reforms is framed in terms of the identification of 'market failures'. Their analysis shows that market failure is both an instrument used critically to problematize existing market-based policy instruments, and at the same time, an evaluative tool that solidifies a framework in which areas like healthcare and transport can be governed as if they were markets.

Reverdy and Breslau study the liberalization of wholesale electricity prices in France since the year 2000. One unexpected outcome of this liberalization was that electricity for long periods became considerably more expensive, and the explanation of this problem became a hot techno-political issue confronting two opposing frameworks. The analysis extends an insight suggested by Breslau (2011, 2013) in his previous work. In markets for collective concerns, struggles are not only about market competition. More attention should be paid to the struggles among different economic experts - who mobilize different definitions of the market at stake - at the level of the technical regulation of each area.

Doganova and Laurent compare three different European market-based environmental policies. Contrasting the European Emissions Trading Scheme (ETS) to markets for clean technologies and sustainable biofuels, Doganova and Laurent focus their analysis on how the boundary between markets and policy is empirically constructed. The ETS can be seen as the outcome of such boundarywork. It shows that European environmental markets can be understood in terms of the continuation of the European economic constitution, and of a general European concern for the harmonization of the European market. But, in the other two cases, the authors argue that boundary-work is problematic, as pollutant emissions are re-entangled to local sites, 'sustainable' qualifications are attached to the materiality of fuels, and negotiations among actors are part and parcel of day-to-day market operations.

Neyland, Ehrenstein and Milyaeva compare two market-based interventions in the UK, namely a market-based scheme for e-waste and a Social Impact Bond for children at-risk for going into care. Their study uses tools from Science and Technology Studies to explore the composition and recomposition of such market interventions and the role of accountability devices in this context. The analyses of both cases show how the actors involved in these radical policy interventions critically assess them and how their evaluations displace and create the problems at stake.

Nik-Khah and Mirowski trace the history of market design and contextualize the case studies explored in the previous four papers. The outcome is a surprising story. Not only do the authors show that market design is a reversal of previous economic thought - a few decades ago markets were assumed to be the opposite of planning - but today economists claim an expertise in designing and constructing markets tailor-made to solve various problems. The authors argue that the rise of market 
design can be understood in the context of a particular intersection between formerly parallel streams in economic thought: the science of system and organization developed in the context of the Cowles Commission, and the trust in the market approach pursued by economists related to streams such as Public Choice.

Finally, this paper has attempted to accomplish two main aims. First, it began by introducing the object of study of this special issue. Collectively, the research presented in this issue identifies a new form of governing through market organization. We term the new terrain, 'the organization of markets for collective concerns and their failures'. Second, this text explored the challenges this new object of analysis presents to existing social studies of markets. We focused on three main issues. First, we examined how different varieties of social studies of markets approach markets as instances of organizations, and the problem posed by the cases considered in this issue of how to account for the fluctuating conceptual value of the market-organization pair in the expertise used to implement, design and repair markets for collective concerns. Markets for collective concerns are not only like organization, but also, against and for organization. The second challenge is at the level of conceptualization: in social studies of markets, sociologists are normally expected to provide their own definitions of markets. The challenge provoked by the study of the organization of markets for collective concerns is that social researchers study experts who mobilize their own concepts of markets. We suggest this might push researchers to a different stance. Instead of providing their own concept of market, they have to develop an analytical sensibility that allows them to better identify and understand the concepts of markets mobilized in the field. The last point concerned the political expectations and the role attributed to social scientists in the organization of markets for collective concerns. The discussion here focused on Callon's expectations of 'civilizing markets'. The empirical challenge posed by the papers in this issue is that the organization of markets for collective concerns is not open to all potentially interested actors. The consolidation of professions like market design makes the organization of markets for collective concerns a new sphere of technical expertise. In this context, we suggest that it is worth asking whether the role attributed to social scientists should be limited to assessing situations in terms of failures of markets.

In sum, the papers in this issue add knowledge about new types of market expertise that unfold after the implementation of markets for collective concerns. As importantly, the issue collectively suggests that the social scientists studying such experts may find themselves challenged in new ways. We do not claim to have solved these challenges. We expect future research will explore other forms of engaging social scientists with the solution of pressing collective concerns in previously marketized areas.

\section{Acknowledgments}

Earlier versions of this article were presented in Athens, Copenhagen, London, Torun and Viña del Mar. We are very grateful for comments and suggestions. In particular, we thank Tomás Ariztía, Paul du Gay, Alan Irwin, Sveta Milyaeva and Daniel Neyland and the reviewers of Economy and Society. The conversation that ends in this special issue started in a workshop in 2014 at Copenhagen Business School. We are grateful to those that helped with the organization of the workshop, in particular Julie Munk and Nanna Helene Jensen, both at that time of CBS' Public-Private Platform, as well as to those who participated in the workshop but for different reasons could not be part of the special issue: Nick Gane, Peter Karnøe and Annelise Riles. 


\section{References}

Ahrne, G., Aspers, P. \& Brunsson, N. (2015). The organization of markets. Organization Studies, $36(1), 7-27$.

Aspers, P. (2011). Markets. Cambridge: Polity Press.

Bendix, R. (1945). Bureaucracy and the problem of power. Public Administration Review, 5(3), 194 $-209$.

Berndt, C. (2015). Behavioural economics, experimentalism and the marketization of development. Economy \& Society, 44(4), 567-591.

Blau, P.M. \& Meyer, M. W. (1971). Bureaucracy in modern society. New York, NY: Random House.

Bourdieu, P. (2005). The social structures of the economy. London: Polity.

Breslau, D. (2011). What do market designers do when they design markets? Economists as consultants to the redesign of wholesale electricity markets in the United States. In C. Camic, N. Gross \& M. Lamont (Eds.), Social knowledge in the making (pp. 381-403). Chicago, IL: University of Chicago Press.

Breslau, D. (2013). Designing a market-like entity: Economics in the politics of market formation. Social Studies of Science, 43(6), 829-851.

Buchanan, J. M. (1969). External diseconomies, corrective taxes, and market structure. The American Economic Review, 59(1), 174-177.

Buchanan, J. M. \& Vanberg, V. (1991). The market as a creative process. Economics and Philosophy 7(2), 167-186.

Çalışkan, K. \& Callon, M. (2010). Economization, part 2: A research programme for the study of markets. Economy and Society, 39(1), 1-32.

Callon, M. (1981). Struggles and negotiations to define what is problematic and what is not. In K. Knorr Cetina, R. Krohn \& R. Whitley (Eds.), The social process of scientific investigation (pp. 197-219). Springer: Amsterdam.

Callon, M. (1998a). Introduction: The embeddedness of economic markets in economics. In M. Callon (Ed.), The laws of the markets (pp. 1-57). Oxford: Blackwell.

Callon, M. (1998b). An essay on framing and overflowing: Economic externalities revisited by sociology. In M.Callon (Ed.), The laws of the markets (pp. 244-269). Oxford: Blackwell.

Callon, M. (2009). Civilizing markets: Carbon trading between in vitro and in vivo experiments. Accounting, Organizations and Society, 34(3-4), 535-548. 
Callon, M., Lascoumes, P. \& Barthe, Y. (2009). Acting in an uncertain world: An essay on technical democracy. Cambridge, MA.: MIT Press.

Callon, M., Méadel, C. \& Rabeharisoa, V. (2002). The economy of qualities. Economy and Society, 31(2), 194-217.

Callon, M. \& Muniesa, F. (2005). Economic markets as calculative collective devices. Organization Studies, 26(8), 1229-1250.

Coase, R. H. (1937). The nature of the firm. Economica, 4(16), 386-405.

Coase, R. (1960). The problem of social cost. Journal of Law and Economics, 3, 1-44.

Colander, D. \& Freedman, C. (2019). Where economics went wrong: Chicago's abandonment of classical liberalism. Princeton, NJ: Princeton University Press.

Cooper, M. (2011). Complexity theory after the financial crisis: The death of neoliberalism or the triumph of Hayek? Journal of Cultural Economy, 4(4), 371-385.

Dardot, P. \& Laval, C. (2013). The new way of the world: On neoliberal society. London: Verso.

du Gay, P. \& Vikkelsø, S. (2017). For formal organization: The past in the present and future of organization theory. Oxford: Oxford University Press.

Ericson, R. \& Doyle, A. (2004). Catastrophe risk, insurance and terrorism. Economy and Society, $33(2), 135-173$.

Farías, I. (2014). Improvising a market, making a model: Social housing policy in Chile. Economy and Society, 43(3), 346-369.

Fligstein, N. (1996). Markets as politics: A political-cultural approach to market institutions. American Sociological Review, 61(4), 656-673.

Fligstein, N. (2001). The architecture of markets: An economic sociology of twenty-first-century capitalist societies. Princeton, NJ: Princeton University Press.

Foucault, M. (2008 [1978-9]). The birth of biopolitics: Lectures at the Collège de France, 19781979. (G. Burchell, Trans.). Basingstoke: Palgrave Macmillan.

Fourcade-Gourinchas, M. \& Babb, S. L. (2002). The rebirth of the liberal creed: Paths to neoliberalism in four countries. American Journal of Sociology, 108(3), 533-579.

Frankel, C. (2015). The multiple-markets problem. Journal of Cultural Economy, 8(4), 538-546.

Frankel, C. (2018). The 's' in markets: Mundane market concepts and how to know a (strawberry) market. Journal of Cultural Economy, 11(5), 458-475

Gane, N. (2014). Sociology and neoliberalism: A missing history. Sociology, 48(6), 1092-1106.

Gane, N. (2016). In and out of neoliberalism: Reconsidering the sociology of Raymond Aron. Journal of Classical Sociology 16(3), 261-279. 
Geiger, S., Harrison, D., Kjellberg, H. \& Mallard, A. (Eds.) (2014). Concerned markets: Economic ordering for multiple values. Cheltenham: Edward Elgar.

Gilbert, J. (2005). The forum and the market: The complexity of the social and the struggle for democracy. Ephemera, 5(2), 221-239.

Hayek, F. (1991). Spontaneous ('grown') order and organized ('made') order. In G. Thompson, J. Frances, R. Levačić \& J. Mitchell (Eds.), Markets, hierarchies \& networks: The coordination of social life (pp.293-301). London: Sage Publications.

Jenle, R. P. \& Pallesen, T. (2017). How engineers make markets: Organizing electricity system decarbonization. Revue Française de Sociologie, 58(3), 375-397.

Koselleck, R. (2004). Futures past: On the semantics of historical time. (K. Tribe, Trans.). New York, NY: Columbia University Press.

Lascoumes, P. \& Le Gales, P. (2007). Introduction: Understanding public policy through its instruments - from the nature of instruments to the sociology of public policy instrumentation. Governance, 20(1), 1-21.

Latour, B. (2004). Why has critique run out of steam? From matters of fact to matters of concern. Critical Inquiry, 30(2), 225-248.

Loconto, A. (2010). Sustainably performed: Reconciling global value chain governance and performativity. Journal of Rural Social Sciences, 25(3), 193-225.

Lohmann, L. (2009). Toward a different debate in environmental accounting: The cases of carbon and cost-benefit. Accounting, Organizations and Society 34(3-4), 499-534.

Luhmann, N. (1980). Gesellschaftsstruktur und Semantik. Studien zur Wissenssoziologie der modernen Gesellschaft. Band 1. Frankfurt A.M.: Suhrkamp.

MacKenzie, D. (2009). Making things the same: Gases, emission rights and the politics of carbon markets. Accounting, Organizations and Society, 34(3-4), 440-455.

MacKenzie, D. A. \& Millo, Y. (2003). Constructing a market, performing theory: The historical sociology of a financial derivatives exchange. American Journal of Sociology, 109(4), 107145.

March, J. G. (1962). The business firm as a political coalition. The Journal of Politics, 24(4), 662678.

March, J. G. \& Simon, H. (1993). Organizations (2 ${ }^{\text {nd }}$ Edition). Cambridge: Blackwell Publishers.

McFall, L. \& Ossandón, J. (2014). What's new in the 'New, New Economic Sociology' and should Organisation Studies care? In P. Adler, P. du Gay, G. Morgan \& M. Reed (Eds.), Oxford handbook of sociology, social theory and organization studies: Contemporary currents (pp. 510-533). Oxford: Oxford University Press. 
McMillan, J. (2002). Reinventing the bazaar: A natural history of markets. New York, NY: W. W. Norton \& Company.

Merton, R. K. (1940). Bureaucratic structure and personality. Social Forces, 18(4), 560-568.

Mirowski, P. (2013). Never let a serious crisis go to waste: How neoliberalism survived the financial meltdown. London: Verso.

Mirowski, P. \& Plehwe, D. (Eds.). (2015). The road from Mont Pelerin. Boston, MA: Harvard University Press.

Mirowski, P. \& Nik-Khah, E. (2007). Markets made flesh: Performativity, and a problem in Science Studies, augmented with considerations of the FCC auctions. In D. MacKenzie, F. Muniesa \& L. Siu (Eds.), Do economists make markets? On the performativity of economics (pp. 190224). Princeton, NJ: Princeton University Press.

Mitchell, T. (2007) The properties of markets. In D. MacKenzie, F.Muniesa \& L. Siu (Eds.), Do economists make markets? On the performativity of economics (pp.244-275). Princeton, NJ: Princeton University Press.

Nik-Khah, E. \& Mirowski, P. (2019) On going the market one better: economic market design and the contradictions of building markets for public purposes. Economy and Society, 48(2).

Ossandón, J. (2015). Insurance and the sociologies of markets. Economic Sociology: European Electronic Newsletter, 17(1), 6-15.

Ossandón, J. (forthcoming). How to write after Callon's performativity? In A. Blok, I. Farías \& C. Roberts (Eds.), A Routledge companion to ANT. London: Routledge.

Pallesen, T. (2016). Valuation struggles over pricing-determining the worth of wind power. Journal of Cultural Economy, 9(6), 527-540.

Pallesen, T. \& Jacobsen, P. H. (2018). Solving infrastructural concerns through a market reorganization: A case study of a Danish smart grid demonstration. Energy Research \& Social Science, 41(July), 80-88.

Reijonen, S. \& Tryggestad, K. (2012). The dynamic signification of product qualities: On the possibility of 'greening' markets. Consumption Markets \& Culture, 15(2), 213-234.

Reinecke, J., Manning, S. \& Von Hagen, O. (2012). The emergence of a standards market: Multiplicity of sustainability standards in the global coffee industry. Organization Studies, 33(5-6), 791-814.

Stengers, I. (2014). La propuesta cosmopolítica. Revista Pléyade, 14(Julio-Diciembre), 17-41.

Ureta, S. (2014). Because in Chile [carbon] markets work! Exploring an experimental implementation of an emissions trading scheme to deal with industrial air pollution in Santiago. Economy and Society, 43(2), 285-306. 
Valdés, J. G. (1995). Pinochet's economists: The Chicago School of Economics in Chile. Cambridge: Cambridge University Press.

Weber, M. (1958). From Max Weber: Essays in sociology. (H.H. Gerth \& C. Wright Mills, Trans.). Milton Park: Routledge.

Williamson, O. E. (1979). Transaction-cost economics: The governance of contractual relations. The Journal of Law and Economics, 22(2), 233-261.

Christian Frankel is Associate Professor in the Department of Organization, Copenhagen Business School. His work focuses on organization theory and economic sociology and how approaches within these literatures can and have been used to understand political regulation and other objects of research.

José Ossandón is Associate Professor in the Department of Organization, Copenhagen Business School. His current work focuses on new modes of economic knowledge produced to evaluate, repair and govern market-based policy instruments, and on the encounters between financial firms' market devices and households' accounting and calculative practices.

Trine Pallesen is Associate Professor in the Department of Organization, Copenhagen Business School. Her work focuses on different and conflicting modes of valuing renewable energy, including attempts to reorganize current energy systems through market redesign to accommodate new and fluctuating energy sources. 


\section{Notes}

${ }^{\mathrm{i}}$ Authors listed in alphabetical order.

ii Beside the cases included in this issue, previously published research exist that could retrospectively be labelled case studies of 'markets for collective concerns'. Some examples are MacKenzie's (2009) and Ureta's (2014) studies of carbon trading mechanisms, Mitchell's (2007) analysis of the unsuccessful attempt to use the formalization of property rights in order to fuel a credit market to solve poverty in Peru, Farías' (2014) study of housing markets in Chile, Berndt's (2016) study of anti-poverty policies in Kenya, and Pallesen and colleagues' (Pallesen \& Jacobsen, 2018, Jenle \& Pallesen, 2017) account of a market for 'flexibility' introduced to decarbonize the Danish energy sector.

iii 'Social studies of markets' is a growing field gathering scholars from disciplines such as accounting, marketing, organization theory, anthropology, geography, sociology and social studies of science (see McFall \& Ossandón, 2014, for a panoramic review). The two most influential streams of literature feeding this field come from the 'New Economic Sociology' developed mostly in the US since the mid-1980s, for instance the work of Fligstein and Granovetter, and the combination of Science and Technology Studies and Sociology that grew out of Callon's influential edited volume The laws of the markets. Other relevant sources in this field are Foucault-inspired studies of governmentality, critical accounting and valuation studies, and economic anthropology and geography.

iv As defined in the Oxford Dictionary: 'Concern: a matter of interest or importance to someone'; 'From French corcerner or late Latin concernere (in medieval Latin "be relevant to")'. We prefer 'concern' to 'interest' because it is used less in the sense of rational individual aims. We do not use the term 'problem' because this word (and some of its derivatives such as problematization) is used in a more specific sense in several of the papers in this issue.

v In Fligstein's words: 'The basic insight is to consider structured exchange (i.e. markets) as a field. The social structure of a field is a cultural construction whereby dominant and dominated coexist under a set of understandings about what makes one set of organizations dominant [...] The goal of the dominant actors is to reproduce the advantage and the goal of the dominated is to either directly challenge the dominant or accept a lesser role' (Fligstein, 2001, p. 68). In March's words: 'Basically, we assume that a business firm is a political coalition and that the executive in the firm is a political broker. The composition of the firm is not given; it is negotiated. The goals of the firm are not given; they are bargained. The business organization is properly viewed as a political system' (March, 1962, p. 663).

vi In Weber's words: 'The decisive reason for the advance of bureaucratic organization has always been its purely technical superiority over any other form of organization. The fully developed bureaucratic mechanism compares with other organizations exactly as does the machine with the non-mechanical mode of production' (Weber, 1958, p. 214).

vii The key text is Coase (1960), see also Buchanan (1969). Whether Coase really meant what later became known as the "Coase Theorem" is a contested issue. See Colander and Freedman (2019, Ch. 7) for an account of the role of Stigler in the particular Chicago reading of Coase's discussion on externalities.

viii In Hayek's view, two types of orders have to be sharply distinguished: one based on planning and organization, and the other on spontaneous self-regulation. According to Hayek, '[t]here are several terms available for describing each kind of order. The made order which we have already referred to as an exogenous order or an arrangement may again be described as a construction, an artificial order or, especially where we have to deal with a directed social order as an organization. The grown order, on the other hand, which we have referred to as a self-generating or endogenous order, is in English most conveniently described as a spontaneous order [...]' (Hayek, 1991, pp. 294-295).

${ }^{\text {ix }}$ How these ideas eventually migrated from economics to policy-making around the world is of course another issue that cannot be covered here, but which has received scholarly attention elsewhere (see for instance, Valdés, 1995; FourcadeGourinchas \& Babb, 2002; and the contributions in Mirowski \& Plehwe, 2015).

${ }^{x}$ Also relevant in this context is the work at the intersection of history of economics and the history of sociology recently developed by Gane (2014, 2016).

${ }^{x i}$ To provide a simple example: what coffee is, who and what is considered relevant to include in the economic valuation of coffee, for instance on supermarket shelves, is today often contested (see Reinecke et al., 2012). In response, coffee producers and other relevant actors involved in this industry have developed new forms of qualification, for instance a certification that a particular coffee bean is organic, or that it has been produced under fair conditions. For studies that use Callon's approach to the study of controversial goods and the series of re-qualifications this might trigger see Loconto (2010), Reijonen and Tryggestad (2012) and the contributions in Geiger et al. (2014).

xii In Callon's view, controversial issues are and should be dealt with through a particular type of participatory mechanism, namely 'hybrid forums'. In such hybrid forums, diverse and affected agents may voice their concerns and may be taken into account (Callon et al., 2009). As such, we could say that Callon has tried to reunite the two different meanings of the ancient word 'agora': the place of exchange and the place of political deliberation (Gilbert, 2005). The civilized market in this sense is not only an assemblage of hybrid entities, but also, as in Hayek's perspective, an assembly where new solutions to collective issues are to be found. 